\title{
Experimental Comparison Of Different Solar Oven Prototypes Adapted To Rural Zones Of The Guayas Province Coast.
}

\author{
Emérita Delgado Plaza, PhD, Manuel León, Ing. Juan Peralta Jaramillo, PhD. Jean Delgado P, Sr. \\ ESPOL Polytechnic University, Escuela Superior Politécnica del Litoral, ESPOL, (Facultad de Ingeniería en Mecánica y Ciencias \\ de la Producción), Campus Gustavo Galindo Km. 30.5 Vía Perimetral, P.O. Box 09-01-5863, Guayaquil, Ecuador \\ eadelgad@espol.edu.ec,jperal@espol.edu.ec
}

\begin{abstract}
The objective of this paper is to provide an optimized low-cost solar oven for the more than 200,000 households (INEC, 2014) using firewood or coal for cooking in the rural sectors of Ecuador coastal zones. According to the Köppen-Geiger classification, those zones are identified as an Aw region (i.e., humid), with abundant cloudiness and high temperatures. Currently, there are a large number of commercial solar ovens showing high performances in vastly irradiated climates. However, its suitability in low to average irradiation areas is doubtful, not to mention the high costs for households at risk of exclusion.

Considering the climatic and socio-economic conditions of the target population, three different oven prototypes have been designed and tested, always under real sun conditions. The technology has been adapted to be constructed with low-cost local materials of easy access for the inhabitants even those of remote areas.

The effect of the construction components, simple and complex reflection plates and thermal storage has been evaluated. For this, internal and external temperature data, solar irradiation, cooking time and thermal inertia have been monitored and analyzed. The thermal losses have been evaluated using thermographic images. The performance of the proposed prototypes has been compared with the response of the most common commercial ovens.

The results were promising in relation to the food cooking time, lower energy losses by using insulating materials, thermal stability and heat accumulation for a longer time in comparison with the current commercial products.
\end{abstract}

Keywords-- Solar oven, low-cost, thermal response, local materials

\section{INTRODUCTION}

The change in the Ecuadorian productive energy matrix has given a significant shift to the use of renewable energy sources aimed at technological adaptation and functional prototype designs. From the study conducted in the population and housing census in 2010, [1] it was determined that the main source of fuel used for cooking food is liquefied petroleum gas followed by the use of firewood and coal. The main problem associated with certain sectors far from the communities is the socio-economic one that requires the purchase of a $15 \mathrm{~kg} \mathrm{LPG}$ tank, in addition to the distances from the nearest place to obtain the product. Moreover, by using firewood or lignocellulose biomass, smoke pollution is also generated, affecting the people health, and the environmental impact logging trees is added..

In 2013, the Ministry of Electricity and Renewable Energy started a program of installation and use of induction cookers, covering the installation of $220 \mathrm{~V}$ connections. From this, the problem arises in the program such as the lack of connection systems to the network of certain isolated communities and scarce electricity supply in certain marginal rural communities.

From the foregoing, a design is proposed and the subsequent construction of an oven-type model of a solar cooker, built with local materials. It is also intended to design accessories that optimize the use of the kitchen from a heat accumulator, which allows to keep the heat inside the equipment for a longer period and improve its efficiency as a function of time, in addition to place reflective panels with tracking system manual. Achieving a better technological adaptation for this solar oven model, will allow families in the rural and remote sectors to reduce expenses for the purchase and transportation of LPG.

\section{STUDY AREA}

Considering that Ecuador is one of the countries with the highest number of hours of solar irradiation per day, the design and construction of three prototypes of solar ovens are chosen, taking in considertation this, being inexpensive to benefit the communities. The climate of the province of Guayas is classified within the tropical dry to semi-humid climate category [4] according to the Köppen climate classification, there are two seasons: the rainy and humid season from December to May and the dry season from June to November where the annual total rainfall is approximately $1506.5 \mathrm{~mm}$ (INAMHI). During the dry season or cool months (June December) the average temperatures range from $21.65^{\circ} \mathrm{C}$ to $30.8^{\circ} \mathrm{C}$, while in the rainy season or the warm season (January - May) there average temperatures oscillate between

Digital Object Identifier (DOI): http://dx.doi.org/10.18687/LACCEI2018.1.1.296 ISBN: 978-0-9993443-1-6

ISSN: 2414-6390

$1^{\text {th }}$ LACCEI International Multi-Conference for Engineering, Education, and Technology: "Innovation in Education and Inclusion", 19-21 July 2018, Lima, Peru. 
$22.7^{\circ} \mathrm{C}$ and $30.65^{\circ} \mathrm{C}$. The extreme values of temperature are around $20^{\circ} \mathrm{C}$ and $35^{\circ} \mathrm{C}$. The solar annual average irradiation for this region is $4.14 \mathrm{kWh} / \mathrm{m} 2$ per day. [INAMHI] Regarding the winds, these are of low intensity, the records indicate that the predominant direction of the winds comes from the Southwest, with a speed between 1 to $3.0 \mathrm{~m} / \mathrm{s}$ maximum.

\section{DESIGNS OF THE SOLAR COOKER}

A solar oven consists of an insulated box with double or single glass cover, and, in certain cases, fixed reflecting panels allowing maximum use of the solar irradiation towards the surface of the oven, by heating the chamber from the beginning of the greenhouse effect.

This research has been developed by the CDTS(Sustainable, Technological Development Center) that belongs to the Escuela Politécnica del Litoral, ESPOL. It has been proposed an analysis of irradiation, heat accumulators and the design of a manual solar tracker, device that allows better use and incidence of solar irradiation inside the oven. With the adaptation of the tracker to these prototypes, the user will be able to adjust the angle of the panels appropriately, in relation to the angle of incidence of the sun during the day.

\section{A. Analysis of the oven-type cooker}

The analysis of solar oven-type cooker starts from the basic theoretical aspects such as; geography of the study, in this case is the Ecuadorian coast; the incident radiation from the sun on the earth's surface and the variation of the angle of incidence, in order to determine the optimum declination angle, additionally the properties of the food to be cooked must be known in order to perform the energy balance of the heating chamber.

The heat losses are obtained based on the global coefficient of heat transmission, the area of the chamber and the temperature difference between the plate and the ambient temperature. [2]

The following assumptions are made for the thermal analysis of the oven:

1) The camera is thermally insulated (stable state)

2) There is no difference in temperature between the lower and upper surface of the plate

3) The flow of heat through the cover and the bottom of the chamber is one-dimensional

4) The energy is uniform throughout the chamber

5) The sky can be considered as a thermal source equivalent to a black body

In relation to the heat accumulator, being the most important part of the oven that will help to conserve heat inside the chamber for a longer time during the cooking process. [3]. It is analyzed from the basic heat equation (1) in order to subsequently obtain the energy stored in the solar oven chamber.

$\mathrm{Q}=($ Tplate - Tfluid $) /(1 / \mathrm{h} \mathrm{A}+\mathrm{e} / \mathrm{KL})$

For the design of the manual solar tracker, several alternatives of movement of the reflective panels have been analyzed to increase the concentration of solar rays inside the oven during the day. For the East-West direction of the sun, the tracker must allow the inclination or decline of the panels, since the apparent movement of the sun in that direction varies during the day from $0^{\circ}$ to $180^{\circ}$, from sunrise to sunset. From the bibliographic reference, it is recommended that the reflective panels be adjusted at an angle of $15^{\circ}$ every hour. In the case of the north - south direction, the panels must be left in a fixed position. [4]

The manual tracker consists of a system with three degrees of freedom that allows to make the movement of the panel smoothly and without problems. These three movements can be described as follows: Folding at the junction between the central rod of the tracker with the reflecting panel, hinged at the joint of the support and the oscillating bushing where the rod enters and sliding between the rod and the oscillating bushing. [4].

To design the tracking strategy in the East - West direction of the panels, it is necessary to analyze the geometric scheme of the light and to determine for which angles of the panels depending on the solar inclination the greater transmittance towards the inner part of the oven. (Figure 1)

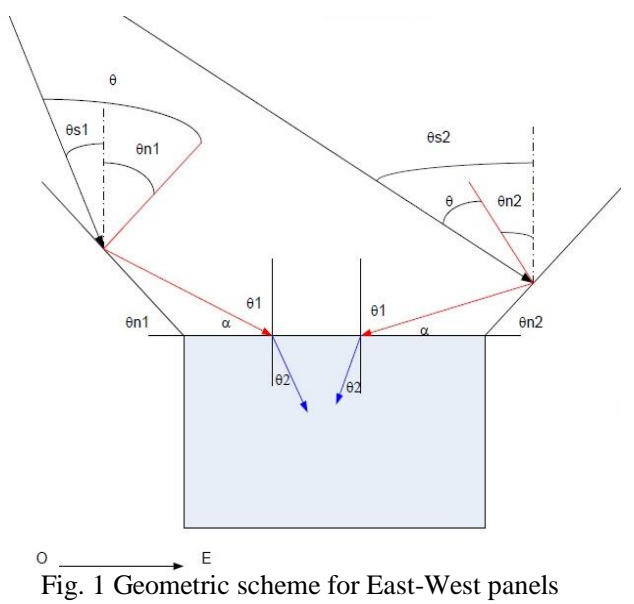

\section{B. Local materials}

During the design process of the kiln-type cooker, prototypes were made using local materials from the study region. The following materials are indicated below:

Chamber: The walls of the oven are made with wood covered with thermal insulation and plates of ultra-bright 
stainless steel. The reflective plates are made with ultra-bright steel.

Manual tracker: The material used for the construction of the manual solar tracker was steel - ASTM A500, steel M8 screws and safety nuts, the regulating shaft was made of transmission steel. The supports of the structure of the mobile plates were manufactured from steel plates (ASTM A500).

Heat accumulator: The accumulator is made of stainless steel and is protected by a layer of black paint; this layer acts as a black body allowing energy to accumulate to a limit and then be emitted to the medium as heat. It should be noted that the heat transfer fluid used in the accumulator is high density thermal oil.

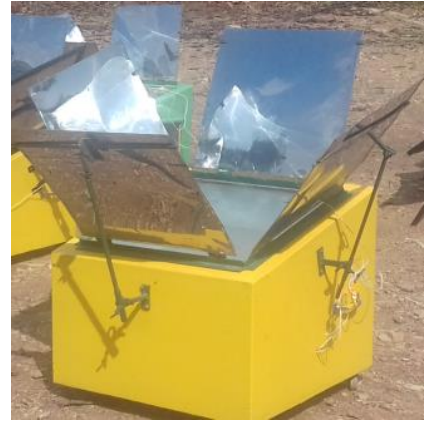

Fig. 2 Prototype1. simple solar oven

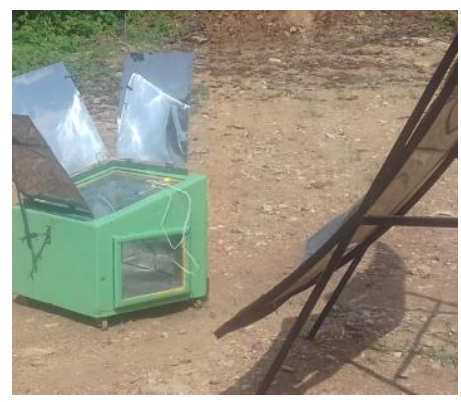

Fig. 3 Prototype2. solar oven with side glasses

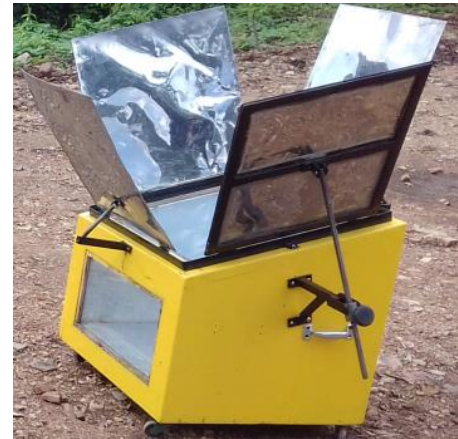

Figure 4. Prototype 3. solar oven with front glass

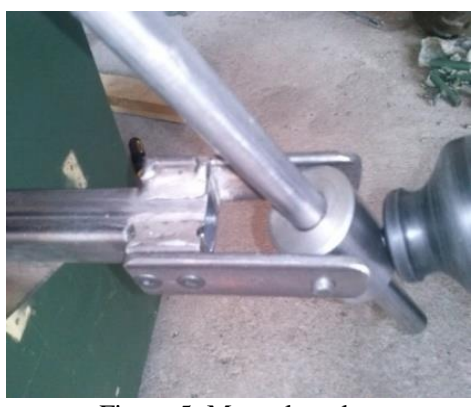

Figure 5. Manual tracker

\section{EXPERIMENTAL TESTS}

Several experimental tests have been carried out for evaluation; the behavior of the oven, cooking time, type of food and determine the best adjustment of the reflective panels and finally the efficiency of the prototype.

As a result, it has been possible to establish the optimal operating condition of the kitchen through the varying angle of incidence over time.

\section{A. Tilt angle for reflecting panels}

During the theoretical analysis of the angle of incidence it was possible to determine which are the ideal angles of placement for the reflective panels observed in Figure 6.

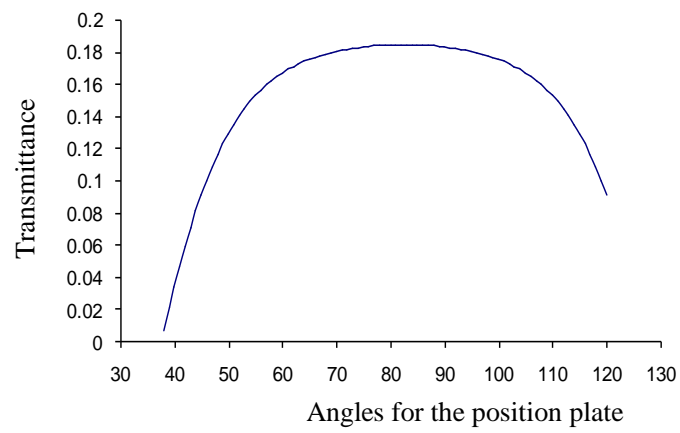

Fig. 6. Angles for the East position plate

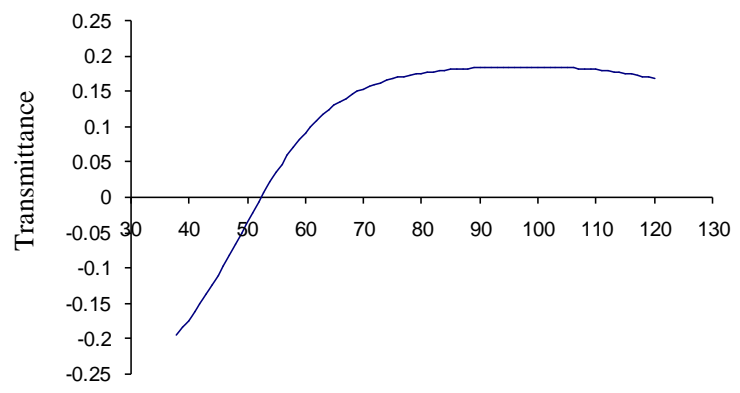

Angles for the position plate.

Fig. 7. Angles for the West position plate.

16 $^{\text {th }}$ LACCEI International Multi-Conference for Engineering, Education, and Technology: "Innovation in Education and 


\section{B. Oven-type cooker}

The experimental tests were carried out for 8 months, during various climatic conditions, between sunny and clear days, as well as cloudy and cold days, which was ideal to observe the operation of the prototypes in different weather conditions.

As can be seen in figure 8a, for cloudy days, the simple solar oven type cooking had less temperature losses when the irradiation was low, this is due to the insulation system in relation to the other models that the loss of heat it is presented by the glasses to the laterals or frontals. In the following figure $8 \mathrm{~b}$, on sunny or partially sunny days, prototypes 2 and 3 gained more heat as a result of the irradiation that is used by the lateral and frontal glasses respectively in each prototype
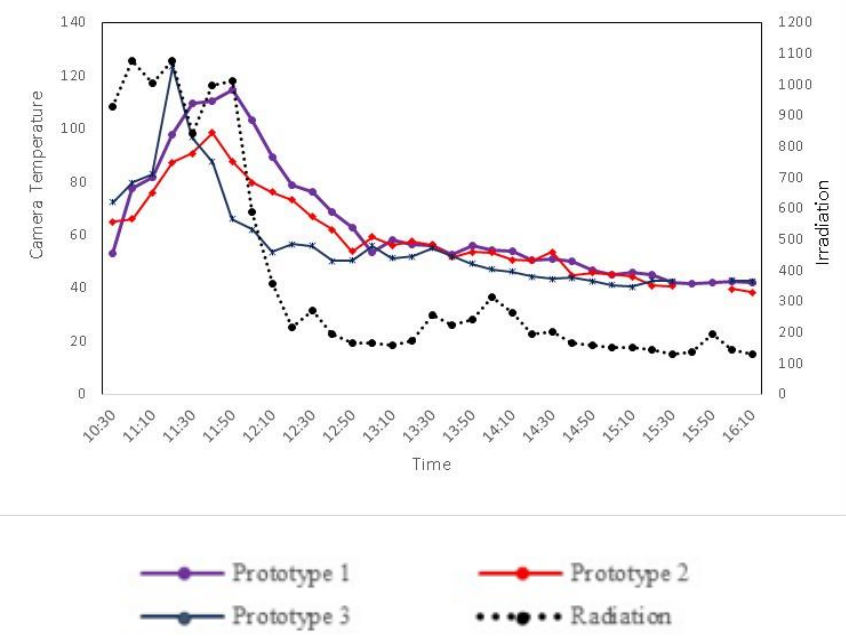

Fig. 8 a. Camera temperature on cloudy days. Prototype 1: simple solar oven. Prototype 2: solar oven with side glasses. Prototype 3: solar oven with front glass.

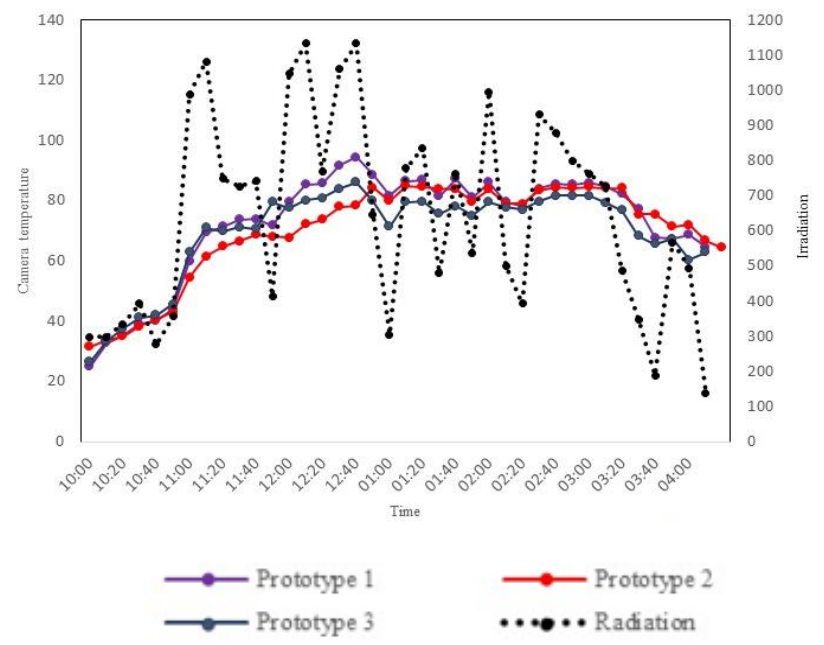

Fig. 8 b. Camera temperature on partly sunny days. Prototype 1 : simple solar oven. Prototype 2: solar oven with side glasses. Prototype 3: solar oven with front glass.
Moreover, in figure 9 is shown the operation of the solar prototypes with a heat accumulator in a partially clear day, it is shown the prototype that has the best performance is the number 2 (solar oven with side glass). As indicated above during the days with good irradiation, this prototype has an extra contribution of light by its front glasses. By adding an accumulator inside the camera, is possible to reach temperatures greater than $10^{\circ} \mathrm{C}$ above the experiment of the camera without accumulator.

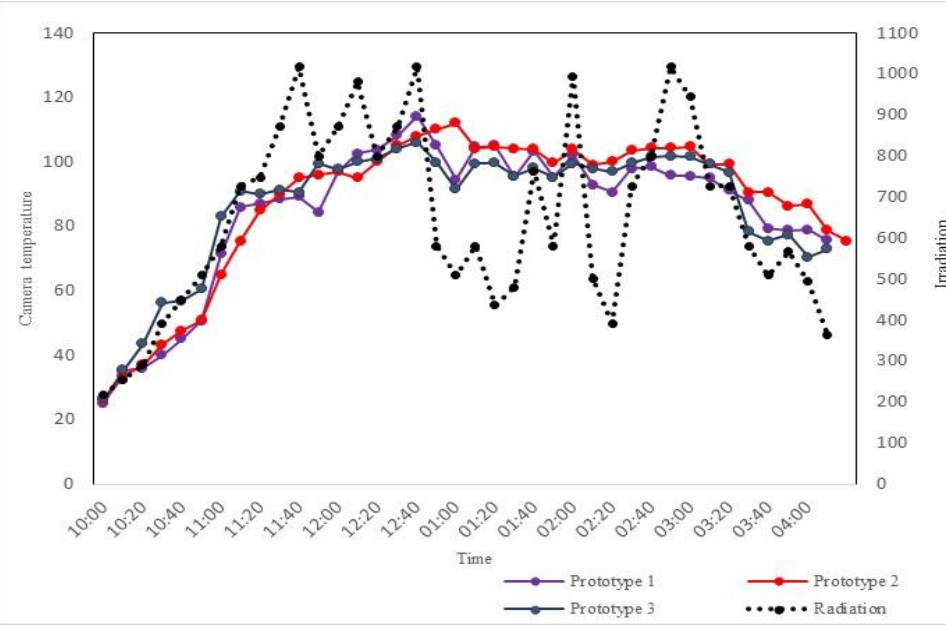

Fig.9 Prototypes with heat accumulators. Partly sunny day temperature. Prototype 1: simple solar oven. Prototype 2: solar oven with side glasses. Prototype 3: solar oven with front glass.

\section{Food cooking}

The cooking time is a determining factor when cooking food, so it must reach a cooking temperature that is different for each food, in order to ensure the denaturation and the elimination of pathogens dangerous for human health [5]. For the case of the solar oven it is important to know this data, since the cooking time of the food in this type of devices is longer, then in traditional cookers. In Table 1, the time it takes cooking a chicken soup is shown, and in figure 9, the internal temperature of the container related to solar radiation that varies with time is shown.

Table 1. Cooking times and characteristics

\begin{tabular}{|c|c|c|}
\hline Climatic conditions & $\begin{array}{l}\text { Reached } \\
\text { temperatures }\end{array}$ & Cooking time \\
\hline $\begin{array}{l}\text { Sunny days } \\
\text { Irradiation } \quad \text { Max: } \\
1176.47 \quad \mathrm{~W} / \mathrm{m} 2 \text {, } \\
\text { Min: } 355.85 \mathrm{~W} / \mathrm{m} 2 .\end{array}$ & $60^{\circ} \mathrm{C}$ to $98^{\circ} \mathrm{C}$ & $\begin{array}{l}\text { Prototype } 1 . \\
1 \text { h } 52 \\
\text { Prototype } 2 . \\
2 \text { h } 30 \\
\text { Prototype } 3 . \\
2 \text { h } 05\end{array}$ \\
\hline
\end{tabular}

16 $^{\text {th }}$ LACCEI International Multi-Conference for Engineering, Education, and Technology: "Innovation in Education and 


\begin{tabular}{|l|l|l|}
\hline $\begin{array}{l}\text { Partially reudy } \\
\text { days. Irradiation } \\
\text { Max: } 1082.06 \mathrm{~W} / \mathrm{m} 2 \\
\text { Min: } 316.70 \mathrm{~W} / \mathrm{m} 2\end{array}$ & $60^{\circ} \mathrm{C}$ to $84.5^{\circ} \mathrm{C}$ & $\begin{array}{l}\text { Prototype } 1 . \\
2 \mathrm{~h} 15 \\
\text { Prototype } 2 . \\
2 \mathrm{~h} 42 \\
\text { Prototype } 3 . \\
2 \mathrm{~h} 22\end{array}$ \\
\hline $\begin{array}{l}\text { Cloudy days. } \\
\text { Irradiation Max: } 275 \\
\text { W/m2 to } 114 \mathrm{~W} / \mathrm{m} 2\end{array}$ & $40^{\circ}$ & $\begin{array}{l}\text { The } \\
\text { prototypes did } \\
\text { not reach the } \\
\text { cocking } \\
\text { temperature }\end{array}$ \\
\hline
\end{tabular}

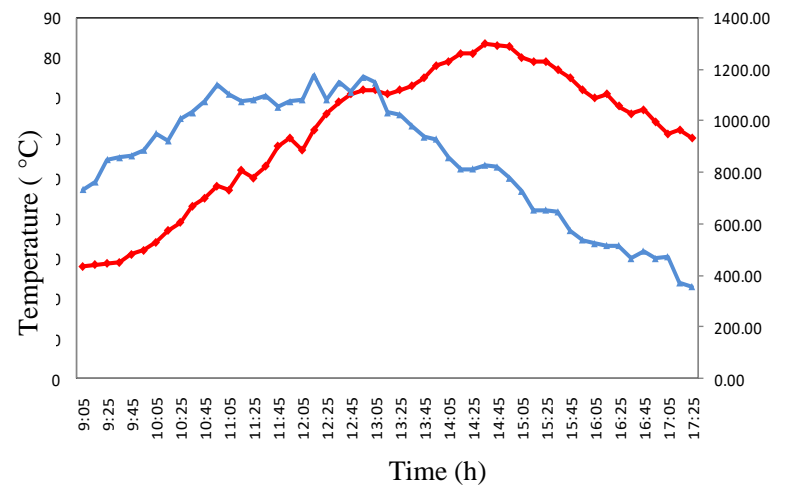

a)

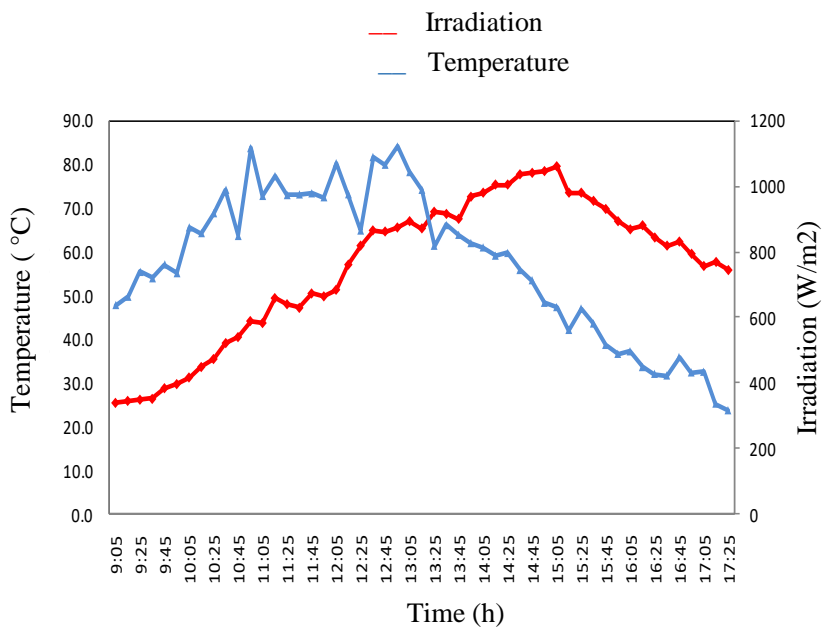

b)

Figure 10. $a$ and $b$. Internal temperature of the container with food, radiation Vs. Time (Partially sunny day)

Analyzing the two cases presented. In the case of figure 10.a, the average temperature reached by the evaporation effect of the soup was $85^{\circ} \mathrm{C}$ from $1.35 \mathrm{pm}$ to $3.45 \mathrm{pm}$ inside the chamber, with a minimum cooking temperature of $73.8^{\circ} \mathrm{C}$ being the recommended temperature for cooking the chicken. Once the maximum temperature of the pot is reached, the temperature drop begins until reaching $60^{\circ} \mathrm{C}$ at 5:45 pm, with an irradiation of $355.85 \mathrm{~W} / \mathrm{m} 2$. In figure it can be seen that the minimum cooking temperature of the chicken was $73.8^{\circ} \mathrm{C}$ at 14.15 p.m., staying above that value until 15.25 p.m.

On the other hand, experimental tests were carried out in weather with cloudy days whose average irradiation was 300 $\mathrm{W} / \mathrm{m} 2$ and ambient temperature of $25^{\circ} \mathrm{C}$. In these conditions the food did not reach the recommended cooking temperature, reaching an average temperature of $45^{\circ} \mathrm{C}$. Therefore, it is necessary to adapt another source of energy as compensation, so the households located in the rural community can cook their food daily.

\section{CONCLUSIONS}

In relation to the design of the oven the heat losses by convection of heat in the surface of the solar oven increases rapidly with the speed of wind, therefore, the cover of glass with minimum iron content reduces the losses of heat by radiation and convection obtaining an absorption of solar radiation up to $6 \%$. Finally, the transmission of the irradiation depends on the thickness of the crystal, therefore to achieve a higher transmissivity it is necessary to use a glass with thin thicknesses.

Solar Oven; It can be concluded that the simple solar oven prototype has better thermal stability for low solar irradiation. On the other hand, prototypes 2 and 3 built with side or front glass will have greater heat loss at low irradiation, but a better performance at high irradiation by the use of reflected light inside the camera product of an external reflector added to the prototypes

The adaptation of a heat accumulator is recommended for these solar prototypes, in order to maintain a thermal gain inside the chamber at the moment of cooking, thus guaranteeing the sudden change of temperature due to solar irradiation.

Food cooking; from the analysis of pot temperature and irradiation that varies with time, it was observed that although the irradiation changes drastically during the day the temperature inside the pot keeps increasing, this is because the pot and the inner air of the solar oven act as accumulators of heat. On the other hand, it can also be concluded that the oven is adequately insulated because the increase in temperature does not obey the reduction of the incident radiation. 


\section{REFERENCES}

[1] INEN. Censo de poblacional y vivienda 2010. Ecuador ,2010

[2] Emerita Delgado. Diseños de cocinas solares para la aplicación en sectores rurales del Ecuador,CDTS- Espol, Ecuador, 2006.

[3] Manuel Leon, Emerita Delgado. Diseño de un sistema de seguimiento solar manual para paneles reflectivos de cocinas solares tipo horno, ESPOL, Ecuador. 2015.

[4] Incropera, Frank P; Dewitt, David P. Fundamentos de transferencia de calor. Sexta Edición. PRENTICE HALL, México, 2015.

[5] Bruque J, Nieto,A. Diseño de una Cocina híbrida (Solar \& Eléctrica), pp. 09-15 ESPOL. Ecuador 2015.

[6] A. M. A. KHALIFA, M. M. A. TAHA. SOLAR COOKERS FOR OUTDOORS AND INDOORS. Energy Vol10. No7. pp819-829.

[7] SAID M. A. IBRAHIM . The performance of a solar cooker in Egypt. Renewable energy. Vol 6. No8. Pp.1041-1050. Elsevier Science Ltd. 1995.

[8] Shyam S. Nandwani. Processor in the climate of Costa Rica. Renewable Energy 32 (2007) 427-441. ScienceDirect. Elsevier.2006.

[9] Pia Piroschka Otte. Solar cookersindevelopingcountries-What istheirkeytosuccess?. Energy Policy63(2013)375-381. Elsevier .2013.

[10] Pia Piroschka Otte. Solar cooking in Mozambique - an investigation of end-user's needs for the design of solar cookers. Energy Policy 74 .pp 366-375. Elsevier .2014

[11] Pranab J. Lahkar, S.K. Samdarshi.A review of the thermal performance parameters of box type solar cookers and identification of their correlations. Renewable and Sustainable Energy Reviews 14. pp 16151621. Elsevier .2010.

[12] Abhishek Saxena. A thermodynamic review on solar box type cookers. Renewable and Sustainable Energy Reviews 15.pp. 3301- 3318. Elsevier .2011.

[13] Hilario Terres.Mathematical Model to Study Solar Cookers Box-Type with Internal Reflectors. Energy Procedia 57. pp 1583 - 1592. Elsevier .2014.

[14] Ashmore Mawire. Solar Thermal Energy Storage for Solar Cookers. Department of Physics and Electronics, Northwest University, Mmabatho, South Africa. Chapter 14.

[15] V. Passamai. SIMULACIÓN DEL COMPORTAMIENTO TÉRMICO DE UNA COCINA SOLAR. ASADES. Avances en Energías Renovables y Medio Ambiente. Vol. 2, $\mathrm{N}^{\circ}$ 1, 1998. Argentina. ISSN 0329-51.4.

[16] L.R.Saravia. TESTEO DE MATERIALES REFLECTORES PARA COCINAS SOLARES DE TIPO CAJA. UNSa -CONICET.

[17] M. Quiroga, L.R.Saravia. APLICACIÓN DEL PROGRAMA SCEPTRE PARA LA SIMUACIÓN DE UNA COCINA SOLAR TIPO CAJA. ASADES. Avances en Energías Renovables y Medio Ambiente Vol. 5, 2001. Argentina. ISSN 0329-5184

16 $^{\text {th }}$ LACCEI International Multi-Conference for Engineering, Education, and Technology: "Innovation in Education and 